\title{
Immaculate Deception: How (and Why) Bankers Still Enjoy a Global Rescue Network Edward J. Kane *
}

\section{Working Paper No. 130}

July $18^{\text {th }}, 2020$

\begin{abstract}
Dodd-Frank is an example of counterfeit reform. It is designed principally to benefit very big banks and it has helped these banks to increase their market share greatly during the last 10 years. The Act provides lesser and contradictory forms of costs and comfort to smaller US bankers and taxpayers, foreign bankers (especially the managers of Deutsche Bank), and foreign governments. Small bankers and taxpayers are encouraged to believe that the 2007-2009 US rescue of the world's biggest banks was a one-time maneuver. But an opposite message is sent through the press as (with great fanfare) the industry absolves and congratulates ex-officeholders: (1) for having transferred massive amounts of subsidized support not just to stakeholders in US megabanks, but also to European bankers and governments, and (2) for keeping the subsidies flowing long past the panic's expiry date. Genuine reform will require changes in fraud laws and an effort to post on a continuing basis the value of the safety-net subsidies individual megabanks enjoy.
\end{abstract}

\section{https://doi.org/10.36687/inetwp130}

JEL Codes: E02, E32, E42, E52, E58

Keywords: Too big to fail, financial safety, financial reform, financial crises, implicit subsidies, political economy

\footnotetext{
* Professor Emeritus, Boston College. This Working Paper is adapted from a chapter in the author's forthcoming book. Comments welcome. The research reported here has been supported by a grant from the Institute for New Economic Thinking. I am grateful to Robert Dickler, Robert Eisenbeis, Thomas Ferguson, Richard Herring and Larry Wall for valuable comments on earlier drafts of this material.
} 
"If you can't dazzle them with brilliance, baffle them with bull..." W.C. Fields

Despite Fed officials' growing willingness to tell us about FOMC meetings and the interest-rate and price-level targets they generate, forms of Fed policymaking that have questionable distributional effects still take place in curtained areas. For example, one can find information on the Fed's many separate bank rescue programs on Fed websites. But a careful analysis of crossprogram subsidized lending to giant US and foreign banks during the GFC (whose size is summarized in Figure 4.1) is sorely needed. Taxpayers deserve to know not only about the size of particular credit flows but about the flow of day-by-day subsidies buried in the "liquidity" support that the Fed provided. To the best of my knowledge, a breakdown of the subsidy flow has never appeared in a Federal Reserve press release or special report. The value and anti-egalitarian character of subsidized support deserves analysis because, until the opportunity costs and adverse distributional character of Fed policies are compiled and presented honestly to the electorate, industry praise for this support should be viewed with a skeptical eye. To my eye, Fed programs appear to have required ordinary US citizens to subsidize their much-richer counterparts. If so, this would explain why megabankers around the world might unite: (1) to promote the idea that what was transferred was only "liquidity," and (2) to praise the troika of Geithner, Paulson, and Bernanke so lavishly.

These three individuals are lucky that no one is out there organizing counter-rallies against them. Themes for such protests would stress that these men: (1) supplied bailout funds to uninsured creditors of firms and governments that were economically insolvent, (2) supplied these funds at unnecessarily generous, below-market terms, (3) imposed no losses or "haircuts" on rescued positions, and (4) failed to recognize and avert the buildup of crisis pressures before things became bad enough to pose a threat to the system.

To justify these actions, Geithner boldly claims that "not imposing losses or haircuts on nondeposit unsecured and secured claims on banks ...helped stabilize the financial system at much lower cost and recapitalized it with private, rather than public money" (Geithner, 2016, p. 24). The last 13 words of this passage have no foundation. At "lower cost" to whom and compared to any and all policy alternatives? Because it does not define what he means by "cost" or specify a concrete policy alternative, the statement has no provable economic content. But what makes my blood boil is his blatant mischaracterization of the nature of the recapitalization that occurred at megabanks. Figure 4.1 shows that plenty of public money was used before private funding was restored.

This leads me to ask why an industry would heap adulation on so lame a spokesperson. My answer is that the praise is simultaneously a payoff for past services and an investment in rebuilding the industry's standing with future regulators. The undeserved accolades serve as a not-so-subtle way of undermining the hard-nosed approach to future insolvency resolution 
envisioned in the Dodd-Frank Act. Industry leaders must hope that persuading the press to treat this generation of crisis managers as conquering heroes will establish a cultural precedent strong enough to force their successors-without much hesitation - to carry forward the elitist priorities the troika adopted during the GFC into future rounds of crisis The troika's policy strategy prevented open insolvencies at US megabanks by making subsidized Fed loans to US megabanks' foreign counterparties (and to the foreign taxpayers that would otherwise have been asked to rescue them). At the same time, they resisted a broad-based bailout of insolvent US homeowners. They stood by as US banks foreclosed on all but a few privileged categories of distressed household mortgage borrowers. Had these officials wished, they could have established parallel programs of equally comprehensive assistance for over-mortgaged US households. But they understood that the distributional controversy over openly subsidizing one set of US citizens at the expense of another might have torn our political system apart. The irony is that the troika found it easier to rescue rich foreigners than impoverished US families.

A precedent is a previous event or action that sets a standard or guide for how one or one's successors should (and therefore probably would) act in similar circumstances in the future. The troika congratulates themselves for having the "courage" to put the interests of foreign bankers and major US financial institutions (including a few of its automobile makers) ahead of ordinary US citizens. Victory laps not only celebrate this approach, but provide opportunities for the troika to make the bull claim of having rescued rich and poor alike from complete and utter ruin [see, e.g., Bernanke, Geithner, and Paulson (2018)]. This is a propaganda exercise of the first order. These and other former Fed and Treasury officials cannot fail to understand that, in accepting so much adulation, they are cementing a series of dangerous precedents. If publicservice norms were more evenly balanced, instead of simply accepting praise, they might feel an obligation to identify the downside of following their lead in the future. Aggressively devising creative, nontransparent, and arguably extralegal ways to transfer massive amounts of US taxpayer resources to wealthy stakeholders in zombie megabanks is a dangerously elitist strategy. An important fourth crisis manager was left out of the celebration: former FDIC Chairman Sheila Bair. In Bair (2019), she argues that, if future crisis managers were to distribute rescue costs in the ways the troika did, they are bound to encounter a series of angry protest movements.

\section{Piling On the Bull}

With a wink and a smile, bankers and politicians assure us that a few carefully crafted words in the Dodd-Frank Act will prove more than enough to prevent similarly anti-egalitarian support from becoming available to the financial industry in the next crisis. The DFA seeks to prevent crises by asking regulators to require banks to post more and better capital. We have established in Chapter 2 that capital requirements lose force the longer they are in place. But megabank lobbyists are speeding up the natural rate of decay under the guise of "custom tailoring" these requirements to the circumstances of different categories of banks. The bull in efforts to soften 
the impact of this legislation is to reformulate the problem of insolvency avoidance so that regulators and supervisors own it. The idea is to make it the government's responsibility to reduce the need for future bailouts rather than bankers' responsibility to keep themselves healthy. Far from fighting this reformulation, captured regulators are scoring points with the industry by pulling the teeth of the balance-sheet requirement structures that were enacted in hopes of keeping the banking system from going off the rails again.

The words with which the DFA purports to outlaw future bailouts (assuming that -- despite supervisors' and regulators' best efforts-- bailouts might somehow be "needed" again) are weak enough already. At best, the DFA installs several loosely crafted administrative barriers to initiating future bailout that in the next crisis the culture of megabank rescue will strongly incentivize regulators to find a way around.

Dodd-Frank is designed to provide contradictory forms of comfort to small bankers, US taxpayers, foreign bankers, and foreign governments at the same time. Small bankers and taxpayers are encouraged to believe that the 2007-2009 US rescue of the world's biggest banks was a one-time maneuver. But an opposite message is sent through the press as (with great fanfare) the industry absolves and congratulates ex-officeholders: (1) for having transferred massive amounts of subsidized support not just to stakeholders in US megabanks, but also to European bankers and governments, and (2) for keeping the subsidies flowing long past the panic's expiry date.

Post-crisis glorification of the bailout policies followed in 2007-2009 has effectively institutionalized finance-centric standards for future crisis management. It is highly unlikely that, in future crises, incumbent Fed and Treasury leaders would dare to ignore the "whatever-ittakes" precedents and expectations these policies managed to establish. This is the central hypothesis of this book. The strong likelihood that this hypothesis is true explains why society needs to make bankers and regulators report --and go on to find ways to rebalance - the distributional costs and benefits of banking-industry rescues.

\section{Captured Regulators Are Incentivized to Overwhelm Us with Bull}

Fractional reserve banking cannot work without customer trust. A bankers' personal reputation for probity used to be the basis for this trust. Today, customer trust has to be strong enough to survive massive waves of evidence that far too many megabankers lack probity and betray counterparty trust whenever they get a chance. Headlines such as "Big Banks Fined a Few Billion Euros (or Dollars) by EU (or US) for Market Misconduct" have become commonplace. According to the Good Jobs First website, Wells Fargo and Deutsche Bank have found it particularly difficult to avoid such headlines. Since 2000, Wells has rung up almost $\$ 15$ billion in fines, while DB has incurred fines of just over $\$ 12.5$ billion. Waves of bad conduct 
resemble crime waves. They make us wonder whether our bank may be ripping us off, too. Such headlines not only undercut our confidence in the ethics of the finance professionals, they shift the burden of assuring honest conduct onto the supervisory system. However, at the same time, the infrequency with which corporate punishments are accompanied by punishments for the individual managers who orchestrated the misconduct further weakens everyone's faith in the justice system. Although headlines show that supervisory systems have not totally failed us, the lack of individual punishments indicate a distressing lack of teeth.

The critical role that third-party supervision and back-up play in maintaining confidence in modern financial systems is what makes legislators' and regulators' resort to bull so dangerous. Policies that make bad behavior seem okay force those who execute these policies to act in concert with the bad guys whose behavior they cover up.

Any parent understands this. Children routinely try to hide questionable behavior from their parents. Parents who turn a blind eye to a child's deceit reinforce two harmful ideas. The first is that the child is the smartest person in the room. The second is that adults do not understand why the child finds unruly behavior so satisfying.

Analogous ideas are used to justify supervisory tolerance of misconduct by regulatees. I think megabankers and Fed officials comfort themselves with the untested hypothesis that ordinary citizens "couldn't handle the truth" about the degree of safety-net exploitation, collusive price manipulation, and routine customer abuse that takes place in the megabanking marketplace day after day. The more deeply a regulator comes to believe this cynical hypothesis, the more he or she is apt to view the industry with a sympathetic eye.

For the industry, maintaining a capacity to put Congressional pressure on regulators and supervisors is a major goal. During the screening process, Senate banking committee members help the industry to implant the idea that regulators owe important duties (and maybe even their jobs) to the industry. This is the first step in maintaining the industry's domination of a longstanding game of regulatory capture. This is a major, but seldom spoken purpose of requiring the U.S. Senate to screen applicants for top regulatory posts.

Another purpose is to teach candidates to expect that Congressional criticism and industry pressure will play a key role throughout their tenure. In particular, regulators must learn that, when it comes to financial innovation, it will be wiser to defer to the judgment of top bankers, at least until agency staff members can tool up sufficiently to explain the antisocial details of the way that the latest circumventive banking products and arrangements actually work.

The second step is on-the-job conditioning. In this phase, lobbyists pressure top regulators in increasingly dubious ways to adjust unpopular rules or patterns of enforcement in their favor. A major lever in the post-appointment lobbying process is the understanding that, once officials 
complete their government service, rewarding jobs and speaking opportunities await them if and only if they respond favorably to industry pressure. If and when this bargain is sealed, a de facto conspiracy is underway. To make it harder for ordinary citizens to see the quid pro quo, both sides prefer bull ways of explaining why rules or supervisory burdens are relaxed and how delayed quid pro quo payoffs work.

Unsurprisingly, the financial world recognizes doubletalk about the regulatory burdens that supposedly accompany subsidy-producing programs as an inside joke. Industry leaders are all too willing to help authorities to lay down reinforcing layers of bull about how much better lightly reconditioned tools of financial regulation and supervision that failed to stop the last crisis will serve us in the future. My purpose in writing this book is to call attention to this unacknowledged game plan and to lay out the consequences of building global strategies of crisis prevention and crisis management on this and other piles of bull.

\section{Have Postcrisis Reforms Made $U s$ (the Citizenry) Safer from Exploitation by Megabankers?}

To grasp the lessons of the Great Financial Crisis, readers must recall and hold onto this book's central distinction. This is the distinction between government support that is explicit and support which is implicit. Explicit support is observable, contractual, and paid for in advance. Bankers pay fees and accept various supervisory burdens that give them a right to receive this support when they need it. On the other hand, implicit support is conjectural. It comes from ex ante expectations about how government officials will behave in different circumstances. Though formally optional, the delivery of this support is incentivized in two ways: (1) by reinforcing officials' fear that failing a big bank might trigger a macroeconomic meltdown and (2) by bureaucratic precedents, industry side payments, and post-government career enhancements that regulators can reap for having avoided or stabilized an incipient crisis. $E x$ post, the bill for the rescues is presented mostly to taxpayers rather than the industry.

The origin of the Great Financial Crisis lies in the accumulation of governments' implicit guarantees to stockholders and top bankers (through incentive-laden forms of managerial compensation). The availability of these guarantees encouraged megabankers to make deals principally in housing finance and derivatives markets-- that strongly risked the ruin of their firms.

As long as the overall economy remained strong, the riskiest participants on the other side of these deals could service their obligations more or less on time. But when housing prices and employment began to fall, so did counterparties' ability to service their contractual obligations. As cash flows from bank assets dried up, bankers found it harder and harder to renew their funding. Rather than take over and formally resolve the insolvency of the world's largest banks, 
top Treasury and Federal Reserve officials decided to cover in full the claims of insured and uninsured creditors alike. Then, without accounting for it accurately, they sent the bill for this to ordinary taxpayers.

It is useful to frame this sequence of events as a parable. Let us suppose that, in an effort to win a prize, a wave of rich bankers leaned too far out of the upper windows of their multistory headquarters. Those that survived were able to direct their fall so that they each landed on a crowd of taxpayers. Numerous injured taxpayers had to be rushed to the hospital, but the bankers were not required to pay the bill for the victims' treatment. Nor did they face any charges for their criminal recklessness. Apparently, governments understand that boys (and occasionally girls) will be "boys."

Regulators did impose a few fines on the daredevils' employers and Congress put out the fake news that, with the help of the Dodd-Frank Act, banks' upper-story windows had been sealed and future contests outlawed. Taxpayers were further encouraged to believe that EU Bail- in Rules and toughened capital requirements have made the world safe from reckless exploitation by European megabankers whose insolvency no one feels a need to resolve.

Financial-reform legislation and the follow-on rulemaking that is needed to make it work each have to wind their way through a gantlet of opposing special interests. As the process proceeds, the product begins to smell more and more like Snake Oil. In any case, the major part of country and global financial safety net protections is not enacted. It is implicit. Expanding or contracting explicit guarantees and requirements has little effect on the supply function of implicit guarantees.

Confidence in the availability and sustainability of implicit support creates powerful incentives for megabankers to pry themselves loose from the bite of capital requirements and other rules over time. This is the message of the Regulatory Dialectic. Today, sponsors of tougher capital requirements and other elaborate rules claim to have found ways to force bank creditors to absorb losses as they occur. But they need to acknowledge that corporate-level reforms are bound to fail eventually. Such reforms fail because they do not directly attack either bankers' appetite for tail risk or regulators' incentives to forbear. Experience teaches us that corporate-level reforms do not and cannot hold their effectiveness over time. Rules beget regulation-induced innovations and these burden-reducing innovations become more and more successful over time. The difficulty governments face in devising and enforcing appropriate punishments for bankers who exploit safety-net protections converts national and regional safety nets into what amounts to a global protection racket operated by --and for the benefit of-- thieving megabankers. 


\section{Crises Begin with Misrepresentations About Troubled Banks' Worsening Condition}

Figure 4.2 names the banks that in 2018 authorities designated as "Global Systemically Important Banks" (G-SIBs). More than a few of these are considered "national champion banks" whose intangible value to their home countries is said to be immeasurable. The figure also shows the additional amounts of tangible book-value capital (BV) that their degree of systemic importance supposedly requires them to book under Basel Committee rules. I say "supposedly" because (as we saw in Chapter 2) troubled banks and their supervisors find ways to report what I call "fake" or "counterfeit" capital (CC) through the use of accounting sleight of hand.

Weakly capitalized banks routinely under-provision for anticipatable loan losses (Vijayaraghavan, 2019). A good example is how a bank can avoid writedown by "evergreening" loans that are not performing. The idea is to keep payments from becoming delinquent by lending customers (in increasingly underhanded ways) the funds needed to make loan payments appear to be on schedule. Because counterfeit capital earns a zero rate of return, the existence of CC reveals itself by forcing the bank's earnings below those of its healthier competitors and its stock price (P) below the bank's book value per share.

One way to test for the existence of counterfeit capital at these banks is to suppose that every GSIB can earn more or less the same market equilibrium rate $(\mathrm{R})$ of return on its per- share stock price. When $\mathrm{CC}$ is large, we can back out the value of nonearning capital by plotting returns on equity against the ratio of $\mathrm{P} / \mathrm{BV}$. A bank's reported capital is the sum of $\mathrm{CC}$ and its genuine capital (GC). The larger is CC relative to GC, the lower the return on reported equity (ROE) and the ratio of $\mathrm{P} / \mathrm{BV}$ must be. This is because $\mathrm{ROE}$ is calculated by dividing the bank's earnings by the sum of its genuine equity and its counterfeit equity. As an example, suppose healthy banks earn an R of $15 \%$ on their genuine equity GC. If (say) half of DB's reported equity were counterfeit, the denominator of its reported ROE would be inflated by a factor of 2 . Reported ROE would equal only which equals $7.5 \%$.

Chapter 2 stresses that, at a distressed bank, the reported (or accounting value) of its assets and liabilities becomes an increasingly poor estimate of either the bank's market or liquidation value. Figure 4.3 shows that P/BV ratios lie below one for megabanks in Europe. This implies (as Figure 4.4 indicates) that the existence of counterfeit capital dilutes their return on equity. The diagram also shows how much stronger are comparable megabanks in North America. That they achieve values of P/BV above one provides evidence that the value of whatever CC they have booked is swamped by the value of intangible (i.e. unbooked) assets such as TBTF guarantees and durable customer relationships.

The amount of counterfeit capital in a banking system is reflected in the growth of central-bank assets relative to GDP. Central banks' assets usually consist of debt owed them by their own sovereign government and by banks they oversee. In several European countries, the market 
value of both classes of assets lies substantially below their book value. Figure 4.5 shows, as a large difference in their clients' counterfeit capital would imply, that post-crisis growth in central-bank assets relative to GDP has leveled off in the US, but is still growing in Europe. Although unbooked losses can be disguised as counterfeit capital, having to sell overvalued assets to cover a deposit run would reveal these assets' lack of loss absorbency. Shortfalls in deposit coverage would have to be openly transferred through the global safety net to taxpayers somewhere.

The US is the country in which banks from other countries hold most of their foreigncurrency reserves. This means that contracyclical variation in the Fed's interest-rate policy instruments affects the allocation of loanable funds across the world.

Figure 4.6 indicates that surges in the percentage of countries whose policy interest rates lie below that of the US (represented by the black line) precede US recessions (the grey areas plotted along the timeline).

My explanation for this phenomenon has two components. First, when in economic booms the Fed uses high US interest rates to choke off consumption, investment, and local government spending in the US, it simultaneously generates unrecognized capital losses that convert some of what has been genuine capital into counterfeit capital on the balance sheets of US banks and variable-rate borrowers. These capital losses weaken US banks and the US macroeconomy.

The second effect is to create a series of cross-country interest-rate differentials. These differentials attract an increased flow of foreign deposits into US megabanks if and as long as these megabanks seem firmly TBTF. Because the outflow of funds from lower-rate countries comes at the expense of reduced loans and investments in their home countries, these differentials spread tight-money conditions across the world. This is why tight money in the US can easily trigger a recession in other countries, too.

\section{Weakness in Efforts to Uncover and Eliminate Counterfeit Capital}

Most (if not all) widespread runs are triggered by the sudden emergence of adverse information about the degree to which important classes of bank assets have sunk underwater. Crisis prevention begins with assembling and empowering teams of well-trained bank examiners to find and surface hidden losses before they can reach ruinous levels. For conscientious examiners, Job One is to double check the accuracy and truthfulness of individual banks' internal estimates of income and net worth.

This is by no means an easy or pleasant task. To avoid closure, managers of distressed banks have at their disposal an ever-expanding catalogue of accounting magic tricks. These tricks are designed to overstate the value of an institution's assets and to prevent accruing losses from 
being fully recognized. Good examiners must exude skepticism and be tough enough to accept that, with most of their clients, relations must be adversarial rather than congenial. Examiners must treat bank managers as if they were contestant illusionists on Penn and Teller's TV Series Fool Us. As in a close-up magic act, a banker presents a "story" designed to distract the examiner from the losses he or she is trying to "vanish." A line of cheerful patter is one of the main tools of a zombie banker, because distracting chatter helps to prevent customers and regulators from seeing or understanding what is going on.

A good place for an examiner to start is to recognize how strongly zombie bankers are incentivized to persuade regulators and other outsiders to downplay the significance and extent of hard-to-conceal below-market rates of return on their institution's reported net worth. Troubled bankers' standard story is to claim that current data on their firm's revenues and costs are not representative of their informed projections of future results. This cover story must plausibly attribute their bank's lack of current profitability to some remediable weaknesses in revenue generation or cost control. This leads them to ask examiners to see this period's low profits as simply a wakeup call about past marketing strategies or systems of cost control that the bank's current managers are already in the process of answering.

Few bankers can confidently claim an ability to turn a bank's revenues, costs or capital weakness around in short order. Nonperforming assets are loans and investments whose ability to generate payments of principal and interest as they come due has become impaired. Impairments that drive a bank into insolvency trace to issues or circumstances in a bank's past life that a banker can seldom remedy quickly. Weakness in a bank's future revenue and cost structures tends to be locked in by its managers' past mistakes. Below-market returns on capital and endlessly falling stock prices (e.g., for Deutsche Bank in Figure 4.7) almost always signal the existence of overly expensive acquisitions, revenue shortfalls and high funding costs caused by nonperforming assets that the bank's managers ought to be forced to write off.

In his annual speech to shareholders on May 23, 2019, DB's current CEO, Christian Sewing, claimed to "have achieved a lot in 2018." His speech emphasized the bank's size, complexity, and importance for the German and European economies. His theme was that the bank "constantly proves that it possesses remarkable resilience and inner strength... which many people underestimate" (Sewing, 2019). I take "resilience" and "strength" as bull codewords for the German government's endless forbearance and the large implicit taxpayer stake its forbearance establishes in this firm.

The possibility of endless forbearance (which I think of as allowing megabankers to engage in a series of renewable regulator-supported gambles) explains why zombieness need not be a permanent condition. Indeed, over the years after the crisis, DB appears to have floated in and out of a zombie condition. 
Figure 4.8 shows why I have singled out Deutsche as a "bad boy bank." Since 2000, its managers' numerous violations of rules and regulations have been sanctioned by over $\$ 12.5$ billion in fines. Observers ought to attribute at least some of its bad behavior to the way that zombieness helps to corrupt a company's managerial culture. Let me describe one of DB's more-successful moves. In late 2008, during the height of the crisis, the bank earned about half a trillion euros in notional value on derivatives trades related to the London Interbank Offered Rate (Libor). The market value of this bet was roughly equal to the approximately $\$ 350$ billion DB was borrowing on a revolving basis from the US Fed (Martens and Martens, 2019). As if that maneuver was not slick enough, Deutsche and several other European megabanks were at the same time conspiring to rig Libor and other benchmark rates (Eaglesham, 2013) to assure that its derivative positions would pay off. If these same conspirators had tried instead to rig card games at a Vegas casino, they would have long since been sleeping with the fishes in Lake Meade. In any case, one has to wonder how the bank's $\$ 79$ billion of notional value in currency and interest-rate contracts will perform going forward, when DB personnel are no longer able to rig the payoffs.

If Sewing proves his doubters wrong, it will probably be because regulators at the Bundesbank, the ECB, and the Fed continue to allow DB to renew period after period a series of large bets on future interest rates and currency values. Managers can place these bets most easily by taking risky positions in swaps and options. DB's plan seems to be to renew these bets until they finally pay off in a big way. As stressed in the theory of the St. Petersburg Paradox, each round of bets is of little market value, but the possibility of a huge payday exists. Because DB is a TBTF megabank zombie, its managers can afford to be patient. The bank's cumulative losses pass through the global safety net to taxpayers around the world. This passthrough of new loss exposures makes the value of the opportunity to keep rolling the bank's losses forward until its solvency is restored very high. As we have said repeatedly, the value of safety-net benefits deserves to be booked simultaneously as an intangible asset of the bank and as intangible liabilities of the various governments that stand behind the global safety net that DB's creditors perceive to guarantee its bets.

Deutsche is widely assumed to have overpaid for the investment-banking franchise it purchased from Bankers Trust in 1998. Although the overpayment has never been written off directly, the loss implied has made itself felt through the poor performance of this sector of the bank and through critics' clamor for DB to sell off this part of its operations. Ever since Google's successful direct listing in 2004, the commission structure, roadshows, and other dictates imbedded in investment bankers' methods of floating an initial public offering have seemed antiquated (Moritz, 2019). Customers on the securities-demand side -hedge funds and mutual funds - are learning to search out and take equity positions in promising private firms on their own. This recalls the way that US households and firms found ways to disintermediate commercial banks in the 1970s. The inevitable loss of business to this kind of disintermediation has eroded the value of investment-banking franchises everywhere. 
The implied size of the overpayment made to BT is consistent with DB's becoming a TBTF zombie bank. The souring of this huge deal is likely to have strongly incentivized the firm's managers to gamble for resurrection ever since (Kane, 1985). It is also consistent with DB's paying top dollar to the head of its poorly performing investment-banking unit. His performance was not being judged for finding positive present-value projects, but for finding projects with a very high upside.

The negative trend in DB's stock price shown in Figure 4.7 suggests that on average DB has lost more gambles than it has won. Its deep dive into money-laundering and corrupt lending (consider its maverick support of Trump enterprises) has damaged the bank's reputation and resulted in a series of crippling fines.

DB's most successful gambles have been on the course of European interest rates. As yields in Europe stayed stubbornly low, the bank's bets against rising rates did very well. Still, in the face of the drain on earnings from other risky moves, one has to admire the ingenuity (if not the integrity) of an internal accounting system that at the end of the first quarter of 2019 enabled DB to show a Common Equity Tier One (CET1) ratio of 13.7 percent.

To me, central bankers' unwillingness to challenge the cooking of DB data indicates their fear that acknowledging and starting to resolve DB's insolvency might trigger another deep recession. A later chapter will explore this issue further, comparing the relative insensitivity of interest spreads that DB and other European megabanks have been paying on their bonds with reliable estimates of variation in their (sometimes-higher) stand-alone probabilities of default over various horizons. For a senior DB bond maturing in 2025, Figure 4.8 shows that the bond's interest spread responds weakly and unreliably to changes in the firm's probabilities of default during its lifetime. For much of 2018-2019, DB's estimated one-year probability of default has exceeded or absorbed most of the spread. If investors were not relying on implicit credit support from the global safety net, changes in the probability of default should pass into the spread more or less on a one-for-one basis. In particular, that DB's default probability could exceed its interest spread for months on end is strong evidence that DB's investors were confident that the global safety net would pick up most of DB's losses if it fell into a full-fledged crisis.

According to DB's website (https://www.db.com/ir/en/shareholder-structure.html), almost 25 percent of DB's voting rights are now owned by six hedge funds (including Cerebus, Hudson Executive Capital, and BlackRock). These are investors who are not afraid of risk and well understand how the safety net works. One suspects that at least some of these aggressive investors acquired their positions at a discount from market price and received special under-the- table assurances about the bank's future plans. Even if they acquired their shares in a discounted deal, they have so far taken a substantial beating on their investment. The easiest way to retrieve their losses is to adopt go-for-broke strategies that pump out round after round of safety-net 
subsidies.

Go-for-broke strategies make sense to savvy shareholders because markets divide the upside and downside of future returns asymmetrically between the bank's government guarantors and its shareholders. Small wins and all losses accrue disproportionately to the bank's guarantors. But the guarantors' claim accrues profits only as long as the bank remains undercapitalized. Spectacular successes are needed before the stockholders can rightly begin to cash in.

I believe that it is significant that the other professional shareholders are allowing an arm of Cerberus to hold the contract to restructure DB. As a private equity (PE) firm, Cerberus has to have a plan that makes sense to its hedge-fund partners. Without inside information and assurances of continuing government support, DB would be a basket case. The facts suggest that Cerberus (which is a major shareholder in Commerzbank as well) eschewed a short-lived plan that would have generated a modest burst of safety-net subsidies by merging DB with fellow zombie Commerzbank to create a super-sized German zombie.

But I fear that Cerebus may not understand that they are sailing in unfamiliar waters. The established PE pattern is to take a public firm private, increase its leverage, use the borrowed funds to pay huge dividends to the private shareholders, and parachute in managers with hyper- incentivized contracts to increase the efficiency of the now-private firm. However, as a national champion bank, DB cannot ever be fully privatized. Its long-lasting insolvency implies that the first fruits of any improvement in DB's cash flows would accrue implicitly to the taxpayers by reducing the value of the implicit guarantees currently support the bank. Finally, because DB is a zombie bank, it is overleveraged already. A concerted effort to pump up its dividends would be challenged by foreign central bankers and call unwelcome attention to the implicit cross- country government support on which its ability to gamble currently rests.

The story which outside investors must believe is that the insiders can clean up the bank's criminal culture, segregate selected nonperforming assets into one or more "bad banks" (i.e., non-core asset units) and cut staff costs by modernizing and automating the flow of information within the firm. They must also believe that the ECB, the Fed, and the Bundesbank will support this strategy until it pays off. In the interim, the ECB must help DB to protect its still-dangerous exposure to Italian debt.

\section{The Role of Currency Swaps in the Global Cover Up}

Any magic show is amusing, even the ones bankers and regulators put on. For me, the amusement is heightened by the Fed's announcing on October 31, 2013 -without what I would call due fanfare - that its "temporary" dollar swap lines with other central banks [including the 
European Central Bank (ECB)] would continue "until further notice" [See Tooze (2018), pp. 482-484].

Bilateral currency swaps are contractual agreements that allow the counterparties to exchange one country's currency for another's today, but require them to reverse their positions at a specified future date. For example, the German central bank might deposit euros with the Fed and withdraw an equivalent amount of dollars today and simultaneously promise to deliver enough dollars to redeem today's euro deposit in 14 days.

Figure 4.9 shows that central-bank swap lines are lightly used today. ${ }^{1}$ Nevertheless, their standby existence cements the presumption that the Fed's leaders feel a responsibility to act as the financial world's "liquidity (and subsidy) provider" of last resort. The Fed is also a generous host to US affiliates and subsidiaries of foreign banks. In fact, foreign institutions hold about 30 percent of the reserve balances held at the Fed. Although the wave of $U S$ bank insolvencies that was uncovered during the GFC has long since been resolved, megabank insolvencies in most other major economies have not. The Fed's demonstrated willingness to make what it mischaracterizes as merely a way to make "liquidity" available as needed to sister central banks in these countries has simultaneously encouraged --and made it possible for-- foreign regulators to delay the insolvency resolution that taxpayers in their jurisdictions desperately deserve.

The Fed's commitment to these swap programs encourages authorities and megabankers in major European and Asian countries to believe that, in the next crisis - as in the one the world has just survived - the Fed will have their backs. Believing that the Fed is backing up what would otherwise be an incomplete and inadequate global safety net, major European regulators can comfortably plan to leave for their successors the painful task of resolving their countries' largest zombie banks.

In the interim, European governments are following a trail blazed in the US by its decades-long support for deeply insolvent thrift institutions in the last century. Zombie banks such as Deutsche Bank are being allowed to gamble for their resurrection with taxpayer money. By this I mean that its managers put funds that a solvent bank would use to support solid business projects into negative-present-value ventures that have the "virtue" of a righthand tail of returns that is deepenough to offer a small probability of one or more "killer" events -such as a revolutionary change in corporate culture, a technological breakthrough in financial contracting, or a world-war driven expansion of Germany's munitions and vehicle industries-- capable of restoring their firm to economic solvency.

European bankers and their governments seem oblivious to lessons to be learned from the way US

\footnotetext{
${ }^{1}$ For example, in mid-November 2018, 43 foreign banks bid for one-week liquidity injections. The aggregate amount they drew down was $\$ 6.7$ billion. In late September, 2019, six banks paid a $2.41 \%$ annual rate on a one- week draw of roughly $\$ 1$ billion.
} 
thrift-institution gambling losses were finally written off. The end game was to allow large US banks to buy up insolvent portfolios and franchises on the cheap.

\section{How Do Fed Swap Lines Work?}

A currency swap line is logically equivalent to a collateralized line of credit, where the collateral consists of foreign currency posted on deposit at the Fed. The Fed's current network of swap lines institutionalizes what was portrayed as a temporary and improvisational program when it was introduced in December 2007. At the foreign central bank's option, it can at any time draw down a contractually specified amount of dollars from the Fed for a period of time (usually one week to three months). The Fed holds some collateral and sets the interest rate that it is to be paid on the deposits it holds. The other central bank relends the dollars to one or more troubled "private" financial institutions in its jurisdiction at a separately negotiated interest rate and the same maturity as the swap.

The explicit insertion of foreign central banks into the Fed's cross-country lending chain is an improvement on the direct lending to insolvent foreign banks that Figure 4.1 shows to have occurred in 2008-2010. This arrangement forces counterpart central banks to price the loans, collect the interest, and to regulate the use made of the proceeds by troubled banks in their country.

But it still allows the Fed to offer subsidized funds to its sister central banks if and when it wishes. The contracts serve two purposes. First, they get around a legislative prohibition on direct Fed lending to foreign central banks. Second, disguising these lines of credit as swap contracts serves as a masking device. Framing these deals as swaps makes it harder for outsiders to understand the degree of subsidization entailed when - to forestall an incipient crisis - the Fed might use foreign central banks as conduits that can promptly deliver US dollar funding to private institutions in their jurisdictions when their banks fall into distress.

If, at maturity, the borrowing central bank finds it hard to deliver the dollars it owes, it must roll over or extend its drawdown. The possibility of forfeiting its deposit at the Fed is an event that none of these institutions wants to see. If a foreign banking system or the ECB were to sink into a deeper and deeper crisis, the Fed can expand its swap positions to offer its central bank all the dollars it wishes.

Still, the foreign currency that the Fed exacts serves as the equivalent of collateral that could not legally be posted with it by a foreign central bank. Like any other collateral, its value could sink below the value of the dollars owed at the expiration of the chain of swaps. To that extent, the swap lines require the Fed to accept currency risk that it could avoid by requiring foreign central banks (like every other Fed counterparty) to post US Treasury bills or other high-quality assets as collateral. Still, one must recognize that the Fed's risk is lessened by the frequency with which 
the swaps' terms are respecified and by the credit capacity of the foreign central bank, which absorbs most of the risk of interim deterioration in the credit standing of the private overseas banks that stand at the end of the central-bank lending chain. This is why the "direct costs" of these deals are trivial (Auer and Kraenzlin, 2009).

It would be hard for central bankers on either side of these underpublicized deals not to know that describing the central-bank halves of this chain of credit as a "reciprocal central-bank liquidity swap" serves to confuse and mislead the public about the extent to which these swaps are loans that will shift default risk onto US taxpayers in the next crisis. Along with the word "swap," the words "reciprocal" and "liquidity" provide "dazzling" semantic cover for what it is at heart merely a confusing way to promise to subsidize foreign banks when they fall into distress.

According to di Mauro and Zettlemeyer (2017), bilateral swap lines between central banks number at least 160. Many of these swap lines do not directly involve the Fed. But US taxpayers should understand that, for the foreseeable future, the "reciprocal" features of the Fed's swap agreements might be better described as one-way streets. It is hard to imagine why either a US bank or the Fed would want to add the additional layers of swap contracting when a discount-window loan could provide much more simply whatever funding the situation needs.

\section{An Imaginary Video of the Global Safety Net in Action}

As of March 2017, Figure 4.10 shows cumulative KDP probabilities of default for major US and foreign banks over different horizons. The numbers suggest that by 2024, if the managers of these banks do not moderate their aggressive pursuit of safety-net subsidies in the meantime, another global crisis could easily occur.

The straightforward way to bail out insolvent banks is to cover the shortfall by levying a special tax. But administratively and politically, a much easier way to resolve the situation is to transfer the assets and liabilities of each ruined bank to a strong acquirer. US regulators have used this method of insolvency not only during crises, but generally (Kane, 1985). It is very likely that stockholders of the world's megabanks are on average much richer than the representative U.S. taxpayer. Figure 4.12 is consistent with the hypothesis that insolvency-resolution and other economic policies have benefited members of the wealthiest ten percent of US households at the expense of the rest of us. In any case, for whatever reason, the data show that richer US households have gained considerably more wealth per household since the crisis began than the lower half of the population. Figure 4.13 shows that, from the start of costly S\&L resolutions in 1989 , the proportionate share of US wealth owned by the least-wealthy 90 percent of US households has declined.

This book asks readers to assume that the Fed's policies and instruments are designed primarily 
to serve the interests of our nation's largest banks and wealthiest citizens. Accepting this premise as a working hypothesis implies that upper classes in the US ought to be grateful for the Fed's stepping into the role of global rescuer of last resort. Megabankers in particular must have recognized that in resolving past banking crises, authorities have increased US megabanks' market power and firmed up their implicit TBTF guarantees.

That a country's wealthiest classes are likely to receive net benefits from a financial crisis is a lesson megabankers ought to have learned from the S\&L mess and from the GFC as well. This leads me to presume: (1) that megabankers recognize the tradeoff between short-term costs and long-run benefits that crises entail and (2) that they are comfortable with the crisismanagement insolvency resolution policies the Fed has devised. To accept willingly the portion of rescue costs that these arrangements impose on them as citizens and taxpayers, US megabankers must expect to gain increased income and market share in the end.

A simple way to communicate the potential benefits that US megabankers might reap from allowing unbooked losses to slosh around for a while in the accounts of DBK and other European zombie banks is to envision that eventually European customers will eventually become scared enough to initiate a depositor run. Customer demands would quickly show the inadequacy and incompleteness of the network of national safety nets protecting these banks (cf. Rajan, 2010). To explain how European and US taxpayers would end up on the hook for European zombie banks' unacknowledged losses, I ask readers to let me load a short video of the end game into their imagination. On the left side of the early frames, we see the leaders of a crowd of EU countries holding their hands out in a begging position. These countries have more or less exhausted the willingness of taxpayers in their countries to bail out their banks any further. The politicians in the first row are recognizable as the leaders of Greece, Italy, and Spain. In the next row, looking slightly less concerned, one can recognize the leaders of Portugal and Ireland.

As the camera pans to the right, we see the leaders of Germany, France, and the IMF. Dressed as clowns, they are loading buckets of European currency into a circus cannon labeled "Formal Regional and International Funding Arrangements." The buckets are not very big and (because of regulatory capture) the cannon looks to be directed - not at the needy countries such as Greece-but at foreign banks (especially German ones) holding substantial positions in the region's zombie banks (cf. Varoufakis, 2017).

In the next sequence, we see a blizzard of currency explode from the cannon. During the next few minutes, leaders of the distressed countries fall all over one another in an attempt to pocket the currency floating in the air and hand it mostly to French and German creditors of their zombie banks. Hardly any bills make it to the ground. But this cannonload fails to satisfy the recipients' needs. They start to jump up and down, shouting repeatedly: "We want more! We need more!"

At this point, the camera pans even further to the right, well past the cannoneers. Here comes 
Uncle Sam. He is pulling a giant caisson of US dollars. The wagon is labeled "Permanent Central-Bank Swap lines." Everybody seems to cheer his arrival, but translated into English they are actually chanting: "It's about time."

Producers of the video decided to cut an additional scene because they found it to be anticlimactic. But it explains the Fed's motivation as a captured regulator and pulls the connection to US megabankers together for me. In this controversial scene, the leaders of the six largest US banks gather around a large crystal ball. The action the crystal displays seems to please them enormously. It shows a series of foreign bankers removing ancient nameplates from their buildings and replacing them with signs like "JP Morgan Chase Europe" and "Bank of America East." 


\section{REFERENCES}

Auer, Raphael, and Sébastien Kraenzlin, 2009. "Money market Tensions and International Liquidity Provision During the Crisis," https://voxeu.org/article/international-liquidityprovision-during-financial-crisis-view-switzerland.

Bair, Sheila, 2019. "Bank Bailouts Propped up the Financial System. But We Should Never Repeat Them," Washington Post (May 5), https://www.washingtonpost.com/outlook/bankbailouts-propped-up-the-financialsystem-but-we-should-never-repeat-them/2019/05/23/f50e001a-7bee-11e9-8edef4abf521ef17 story.html?noredirect=on\&utm term=.6a6b29423edf.

Bernanke, Ben S., Timothy F. Geithner, and Henry M. Paulson Jr., 2018. "What We Need to Fight the Next Financial Crisis," New York Times, (Sept. 12), https://www.nytimes.com/2018/09/07/opinion/sunday/bernanke-lehman-anniversaryoped.html.

di Mauro, Beatrice W., and Jeromin Zettelmeyer, 2017. "The New Global Safety Net: Struggling for Coherent Governance in a Multipolar System," CIGI Essays in International Finance, 4.

Eaglesham, Jean, 2013. “Bank Made Huge Bet, and Profit, on Libor,” Wall Street Journal, (Jan. 10), https://www.wsj.com/articles/SB10001424127887324442304578231721272636626.

Geithner, Timothy F., 2016. "Are We Safer? The Case for Stengthening the Bagehot Aresenal," 2016 Per Jacobson Lecture, www .perjacobson.org/lectures/100816.pdf.

Kane, Edward J., 1985. The Gathering Crisis in Federal Deposit Insurance, Cambridge: MIT Press.

Martens, Pam, and Russ Martens, 2019. “After a \$354 Billion US Bailout, Germany’s Deutsche Bank Still Has \$49 Trillion in Derivatives," http://wallstreetonparade.com/2019/04/aftera-354-billion-u-s-bailout-germanys-deutsche-bank-still-has-49-trillion-in-derivatives/.

Moritz, Michael, 2019. "Investment Banks are Losing their Grip on IPOs: The Technology Sector in Particular Now Favours Direct Listing," Financial Times (Aug. 18). https://www.ft.com/content/7985bb78-bdbf-11e9-9381-78bab8a70848.

Sewing, Christian, 2019. "Christian Sewing's Speech at the Annual General Meeting 2019," https://www.db.com/newsroom news/2019/christian-sewing-en-11497.htm.

Rajan, Raghuram, 2010. Fault Lines: How Hidden Fractures Still Threaten the World Economy. 
Princeton: Princeton University Press.

Taleb, Nassim N., 2018. Skin in the Game: Hidden Asymmetries in Daily Life. New York: Random House.

Tooze, Adam, 2018. Crashed: How a Decade of Financial Crises Changed the World. New York: Viking.

Varoufakis, Yanis, 2017. Adults in the Room: My Battle with the European and American Deep Establishment. New York: Farrar, Straus, and Giroux.

Vijayaraghavan, Rajesh, 2019. "Recognizing Loan Losses in Banks: An Examination of Alternative Approaches.” https://ssrn.com/abstract=3398690. 
FIGURE 4.1

GLOBALIZATION OF US NET OCCURRED DE FACTO DURING THE 2007-10 CRISIS: THE FED USED ITS LAST-RESORT LENDING POWERS CREATIVELY TO PROVIDE SUBSIDIZED FUNDING TO MANY OF THE LARGEST BANKS IN THE WORLD (Size of Fed Loans 8/2007-4/2010)

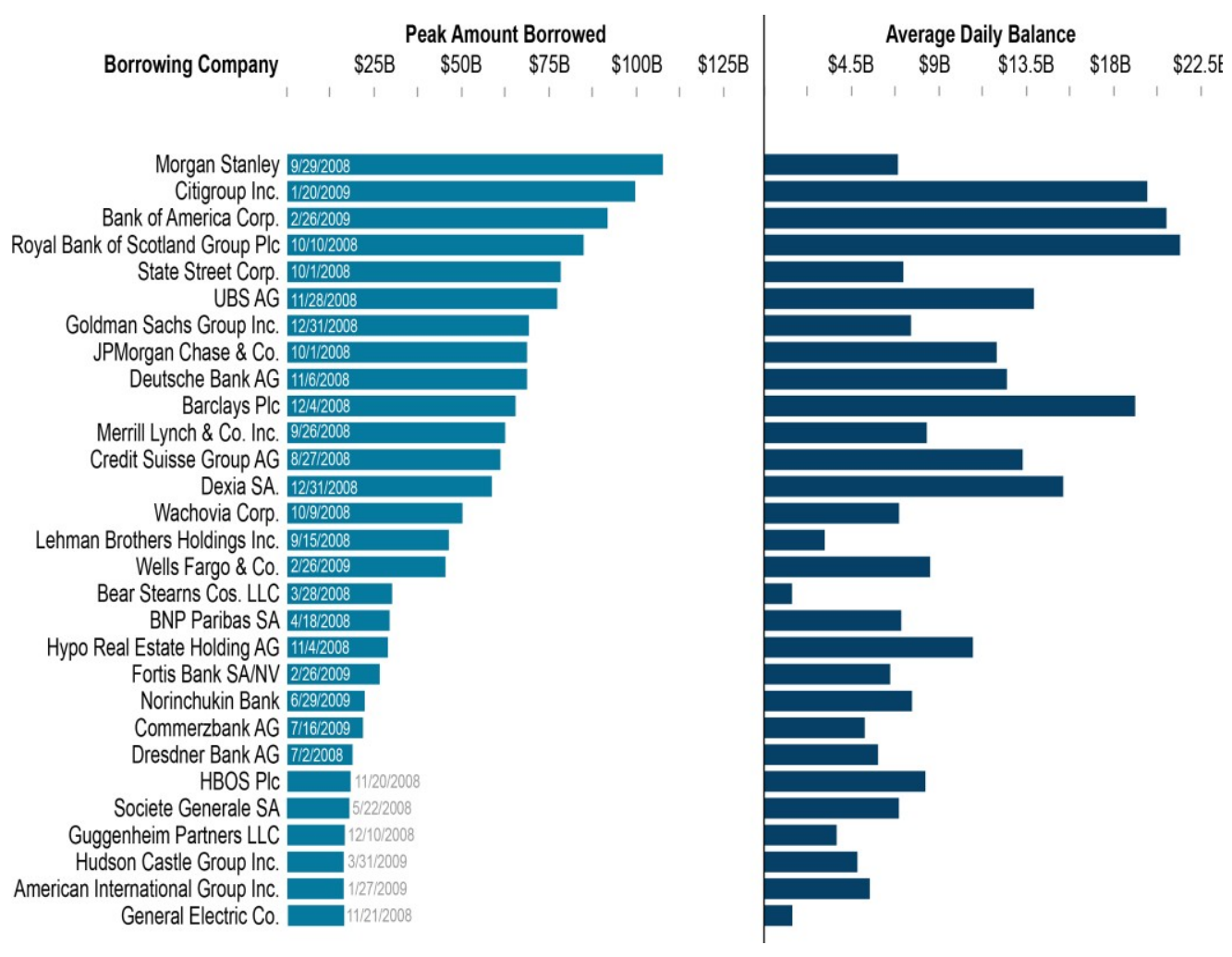

Source: Bradley Keoun and Phil Kuntz, 2011, "Wall St. Aristocracy Got \$1 Trillion," Bloomberg.com, August 22 (transmitted to me by Richard Herring). 
FIGURE 4.2

\section{G-SIBS AS OF NOVEMBER 2018* ALLOCATED TO BUCKETS CORRESPONDING TO REQUIRED LEVELS OF ADDITIONAL CAPITAL BUFFERS}

\begin{tabular}{|c|c|}
\hline Bucket & G-SIBs in alphabetical order within each bucket \\
\hline $\begin{array}{c}3^{* *} \\
(3.5 \%)\end{array}$ & (Empty) \\
\hline $\begin{array}{c}4 \\
(2.5 \%) \\
\end{array}$ & JP Morgan Chase \\
\hline $\begin{array}{c}3 \\
(2.0 \%)\end{array}$ & $\begin{array}{l}\text { Citigroup } \\
\text { Deutsche Bank } \\
\text { HSBC }\end{array}$ \\
\hline $\begin{array}{c}2 \\
(1.5 \%)\end{array}$ & $\begin{array}{l}\text { Bank of America } \\
\text { Bank of China } \\
\text { Barclays } \\
\text { BNP Paribas } \\
\text { Goldman Sachs } \\
\text { Industrial and Commercial Bank of China Limited } \\
\text { Mitsubishi UFJ FG } \\
\text { Wells Fargo }\end{array}$ \\
\hline $\begin{array}{c}1 \\
(1.0 \%)\end{array}$ & $\begin{array}{l}\text { Agricultural Bank of China } \\
\text { Bank of New York Mellon } \\
\text { China Construction Bank } \\
\text { Credit Suisse } \\
\text { Groupe BPCE } \\
\text { Groupe Crédit Agricole } \\
\text { ING Bank } \\
\text { Mizuho FG } \\
\text { Morgan Stanley } \\
\text { Royal Bank of Canada } \\
\text { Santander } \\
\text { Société Generale } \\
\text { Standard Chartered } \\
\text { State Street Sumitomo } \\
\text { Mitsui FG UBS } \\
\text { Unicredit Group }\end{array}$ \\
\hline
\end{tabular}

Source: Financial Stability Board (FSB)

\footnotetext{
${ }^{*}$ A B-SIB is a financial institution that has been designated as a Global Systemically Important Bank by the FSB in consultation with the Basel Committee on Banking Supervision (BCBS) and national authorities. Compared with the list of G-SIBs published in 2017, the number of banks identified as G-SIBs do not change much from year to year. In 2018, the number decreased from 30 to 29. One bank (Groupe BPCE) was added to the list, and two banks (Nordea and Royal Bank of Scotland) were removed. Two banks have moved to a lower bucket: Bank of America moved from bucket 3 to bucket 2 and China Construction Bank has moved from bucket 2 to bucket 1 . ** The bucket (or categorical) structure is defined in Table 2 of the Basel Committee document Global systemically important banks: updated assessment methodology and the higher loss absorbency requirement, July 2013. The numbers in parentheses are the required level of additional common equity loss absorbency stated as a percentage of so-called risk-weighted assets that each G-SIB will be required to hold in 2020.
} 
FIGURE 4.3

WHETHER A BANK IS EXPLOITING TAXPAYER SUPPORT CAN BE LOOSELY DETERMINED BY LOOKING AT ITS RATIO OF PER-SHARE MARKET PRICE TO BOOK VALUE (Feb 2019)

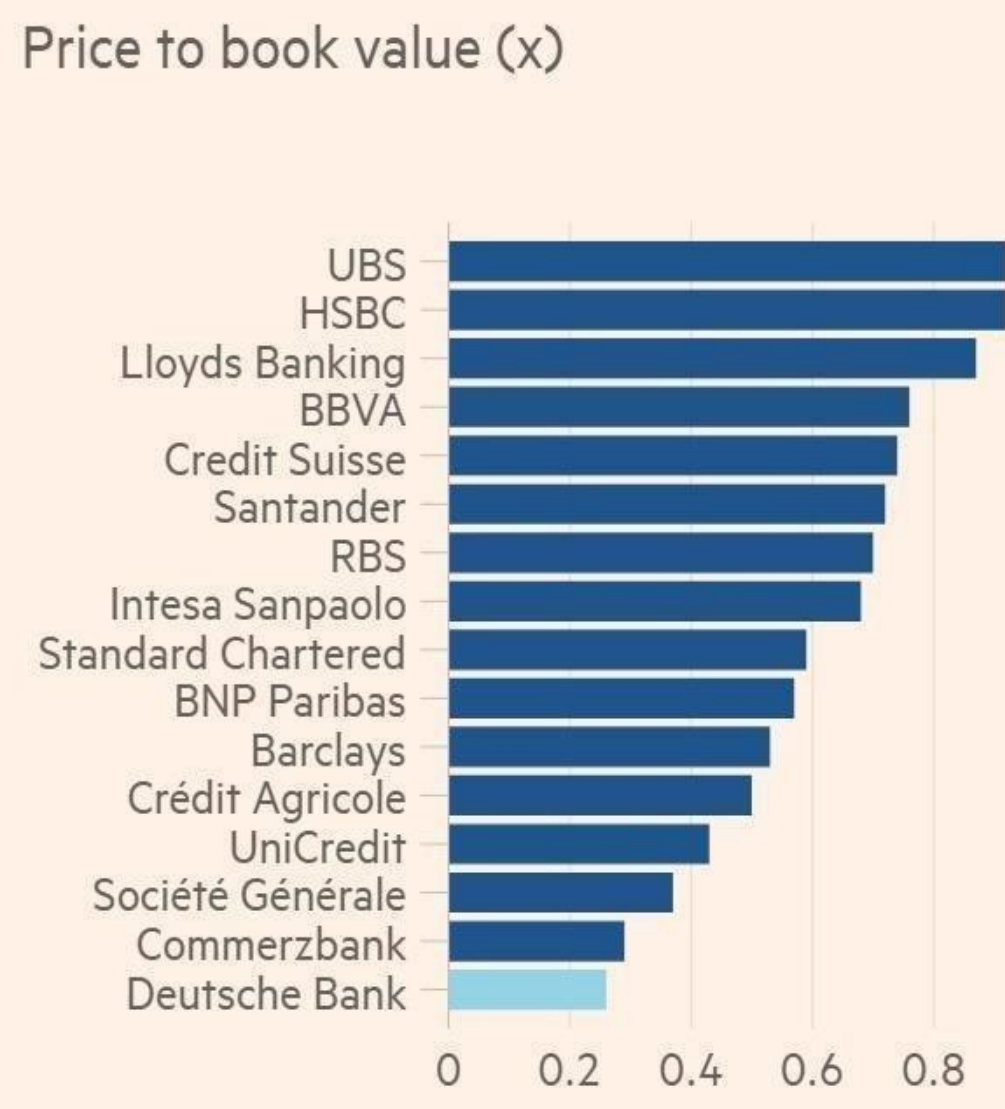

Source: Bloomberg

(c) FT 
FIGURE 4.4

\section{RATIO OF STOCK PRICE TO BOOK VALUE AND RETURN ON EQUITY AT G-SIB BANKS BY REGION}

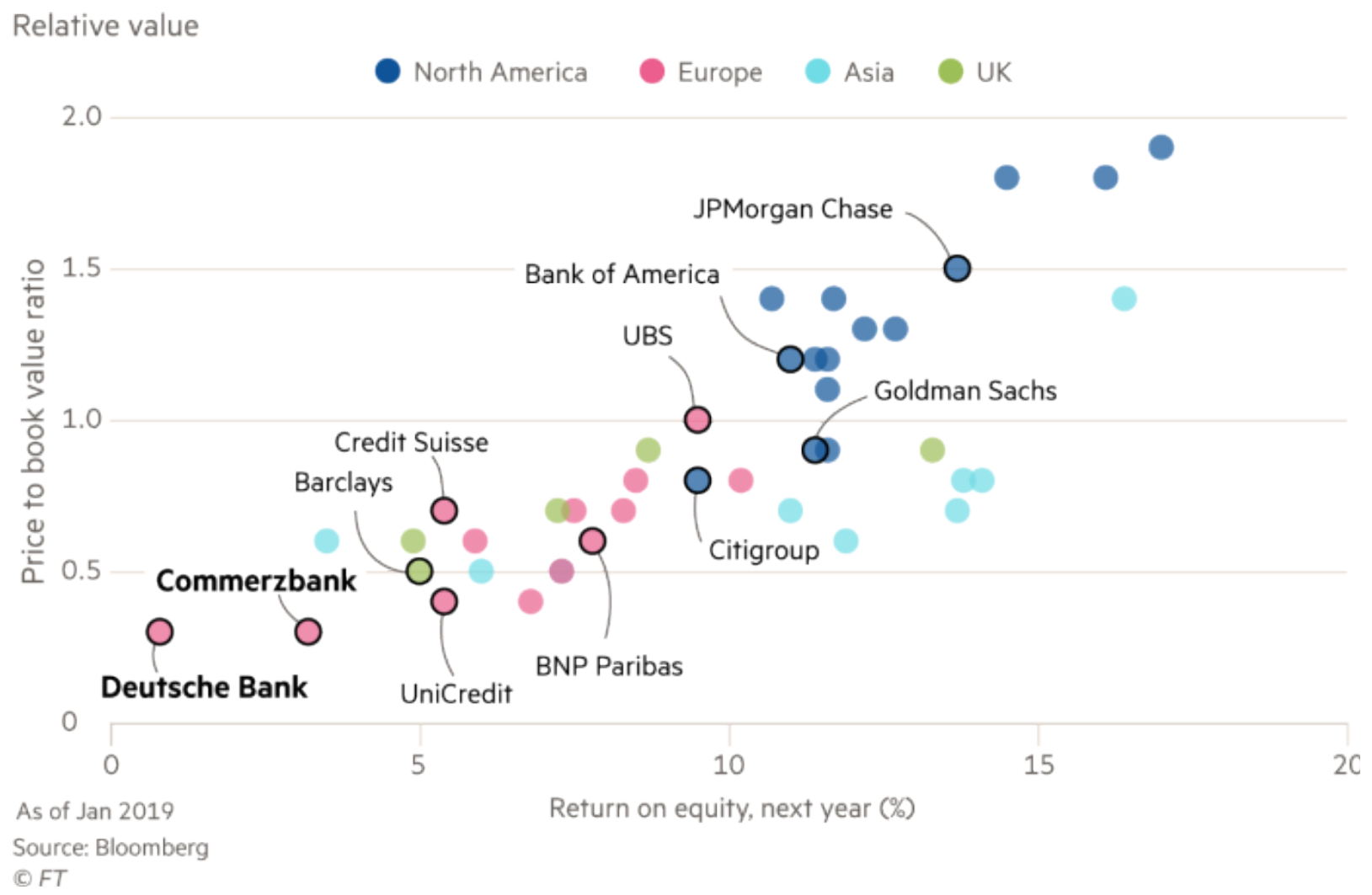

Note: Banks labeled blue or red in Figure 6.3 are identified by name in this figure. Among US banks, only Citigroup and Goldman Sachs show any evidence of counterfeit capital. 
FIGURE 4.5

\section{CENTRAL BANK ASSETS AS A PERCENTAGE OF GDP}

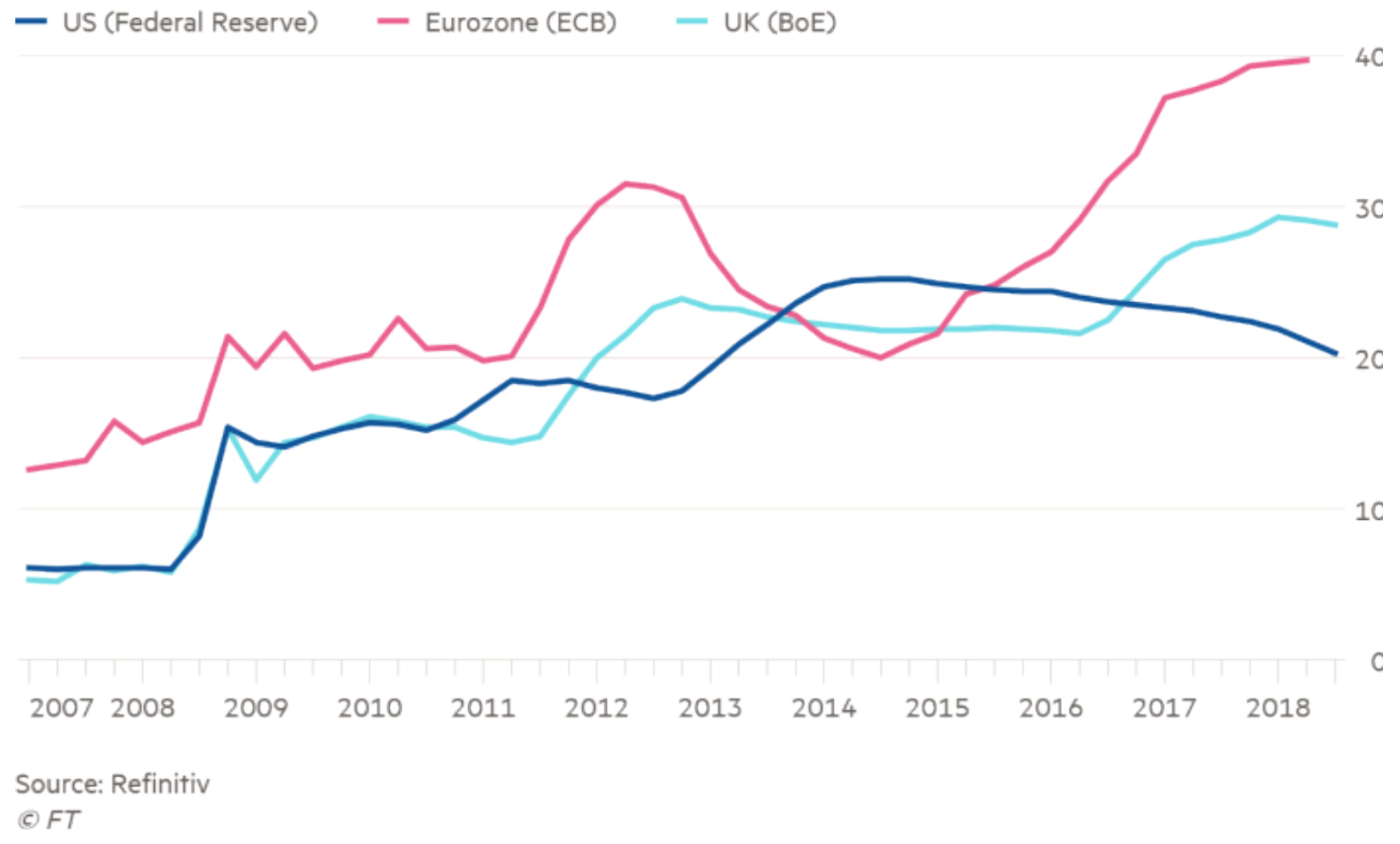


FIGURE 4.6

Developed Country Policy Rates

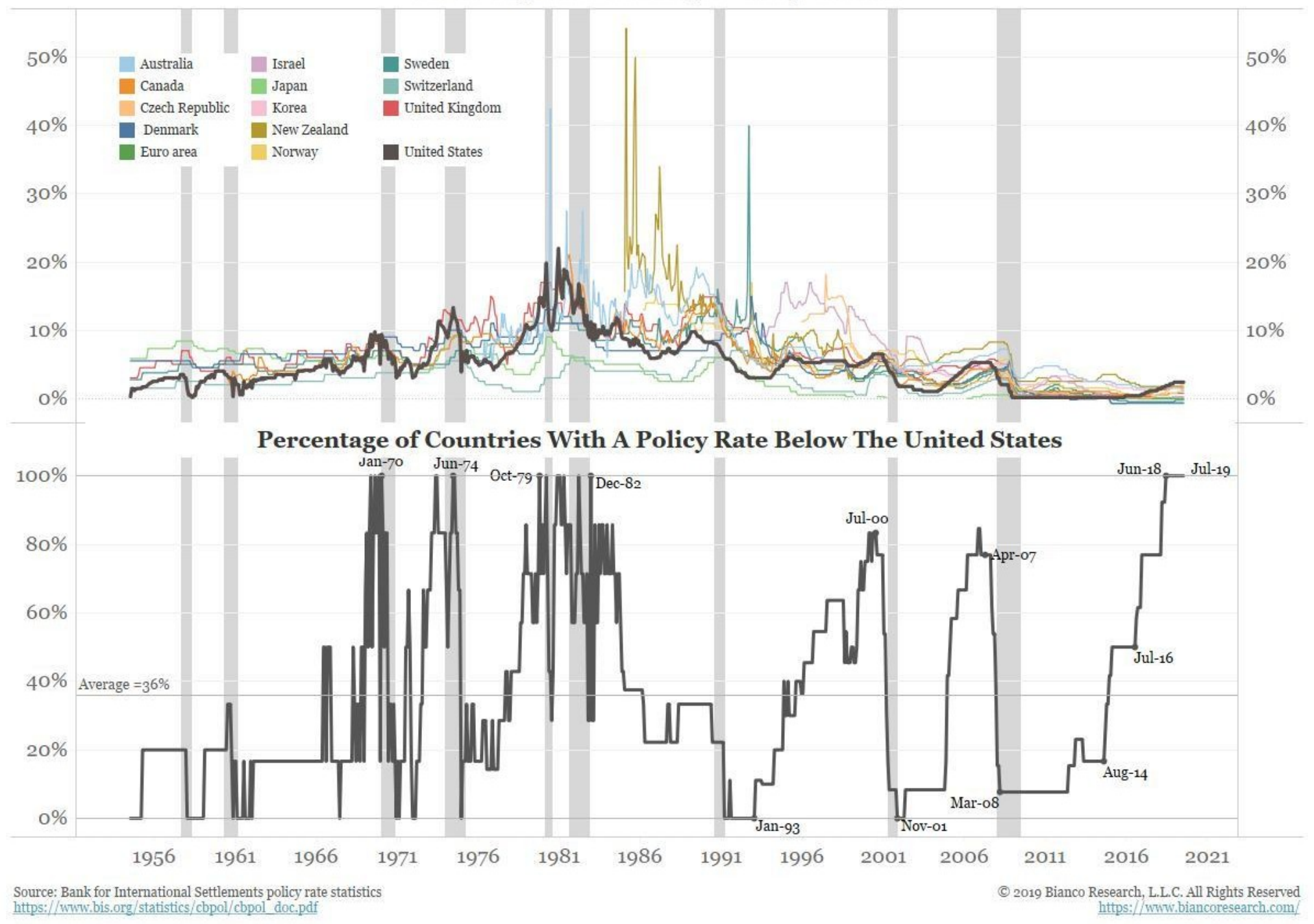




\section{FIGURE 4.7}

Deutsche Bank's tumble

$€$ per share

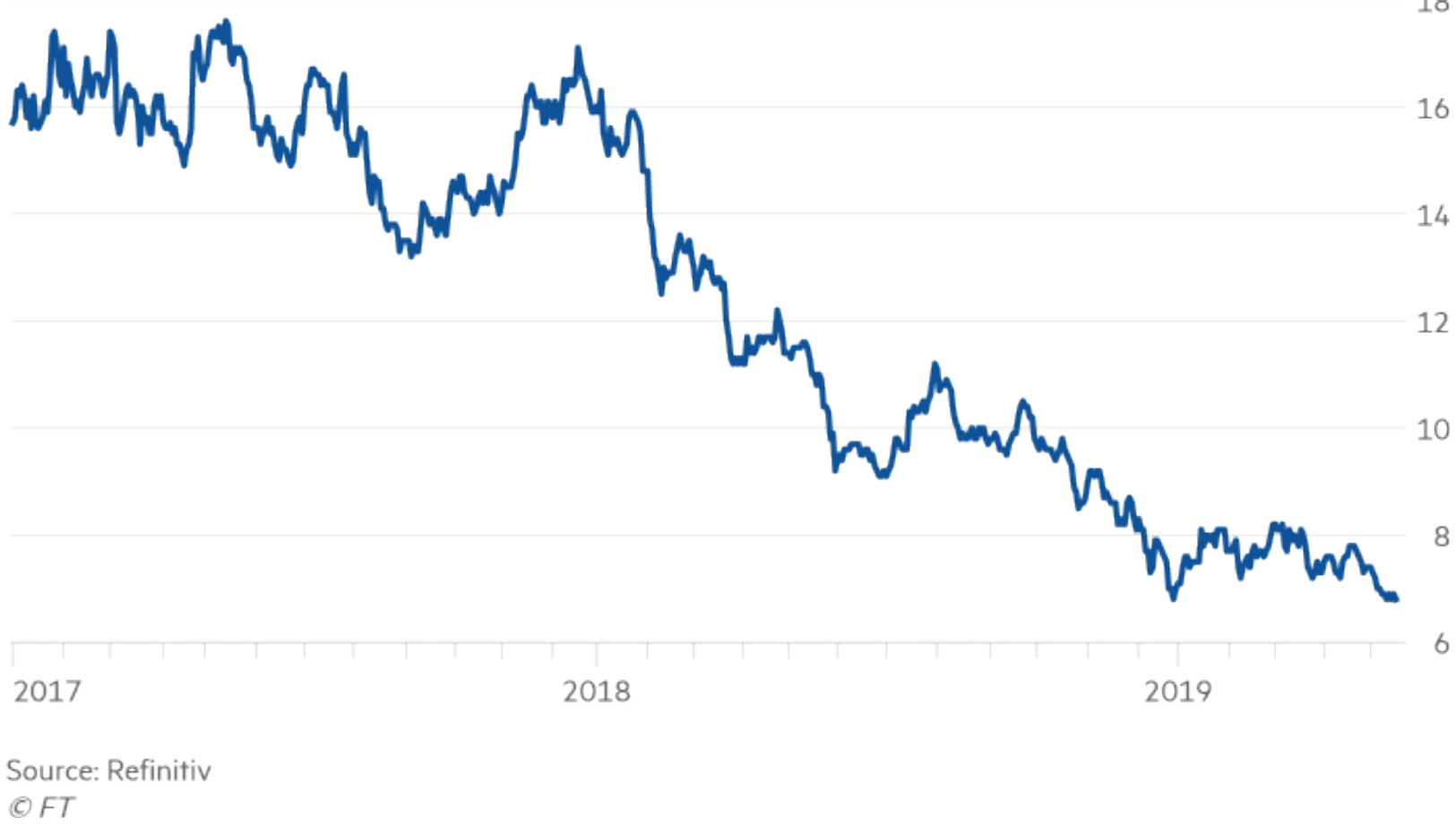


FIGURE 4.8

BREAKDOWN OF \$12,552,639,548 IN FINES FOR VIOLATIONS PAID BY DEUTSCHE BANK SINCE 2000

\begin{tabular}{|c|c|c|}
\hline Top 10 Primary Types of Offense & Penalty Total & $\begin{array}{c}\text { Number of } \\
\text { Records }\end{array}$ \\
\hline toxic securities abuses & $\$ 9,472,300,000$ & 4 \\
\hline interest rate benchmark manipulation & $\$ 1,951,600,000$ & 5 \\
\hline tax violations & $\$ 679,659,153$ & 3 \\
\hline investor protection violation & $\$ 216,144,145$ & 11 \\
\hline securities issuance or trading violation & $\$ 103,200,000$ & 2 \\
\hline banking violation & $\$ 58,000,000$ & 1 \\
\hline anti-money-laundering deficiencies & $\$ 41,000,000$ & 1 \\
\hline benefit plan administrator violation & $\$ 21,900,000$ & 1 \\
\hline data submission deficiencies & $\$ 4,150,000$ & 2 \\
\hline accounting fraud or deficiencies & $\$ 3,000,000$ & 1 \\
\hline
\end{tabular}

Source: https://violationtracker.goodjobsfirst.org/parent/deutsche-bank. 
FIGURE 4.9

INSENSITIVITY OF THE INTEREST SPREAD ON A DEUTSCHE BANK BOND MATURING IN 2025 TO CHANGES IN KAMAKURA ESTIMATES OF THE FIRM'S

1-YEAR, 5-YEAR AND 10-YEAR PROBABILITY OF DEFAULT

DEUTSCHE BANK AG

Entity Deutsche Bank AG Issue FXDFR NT REDEEM 24/05/2028 USD 200000 Callable Y Seniority Senior Subordinate

Most Recent Trade Date 06/14/2019 Price \$89.29 Volume 1,359.000 Spread NA Yield NA

View By Price Volume weighted price based on actual trades

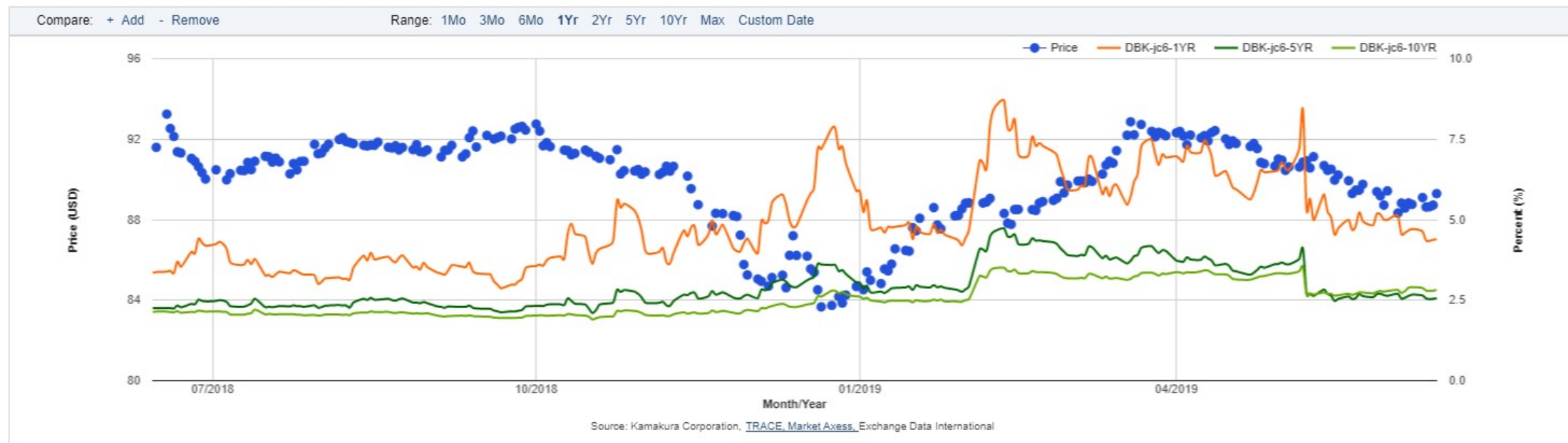


FIGURE 4.10

FRED $\approx$ - Central Bank Liquidity Swaps held by the Federal Reserve: All Maturities

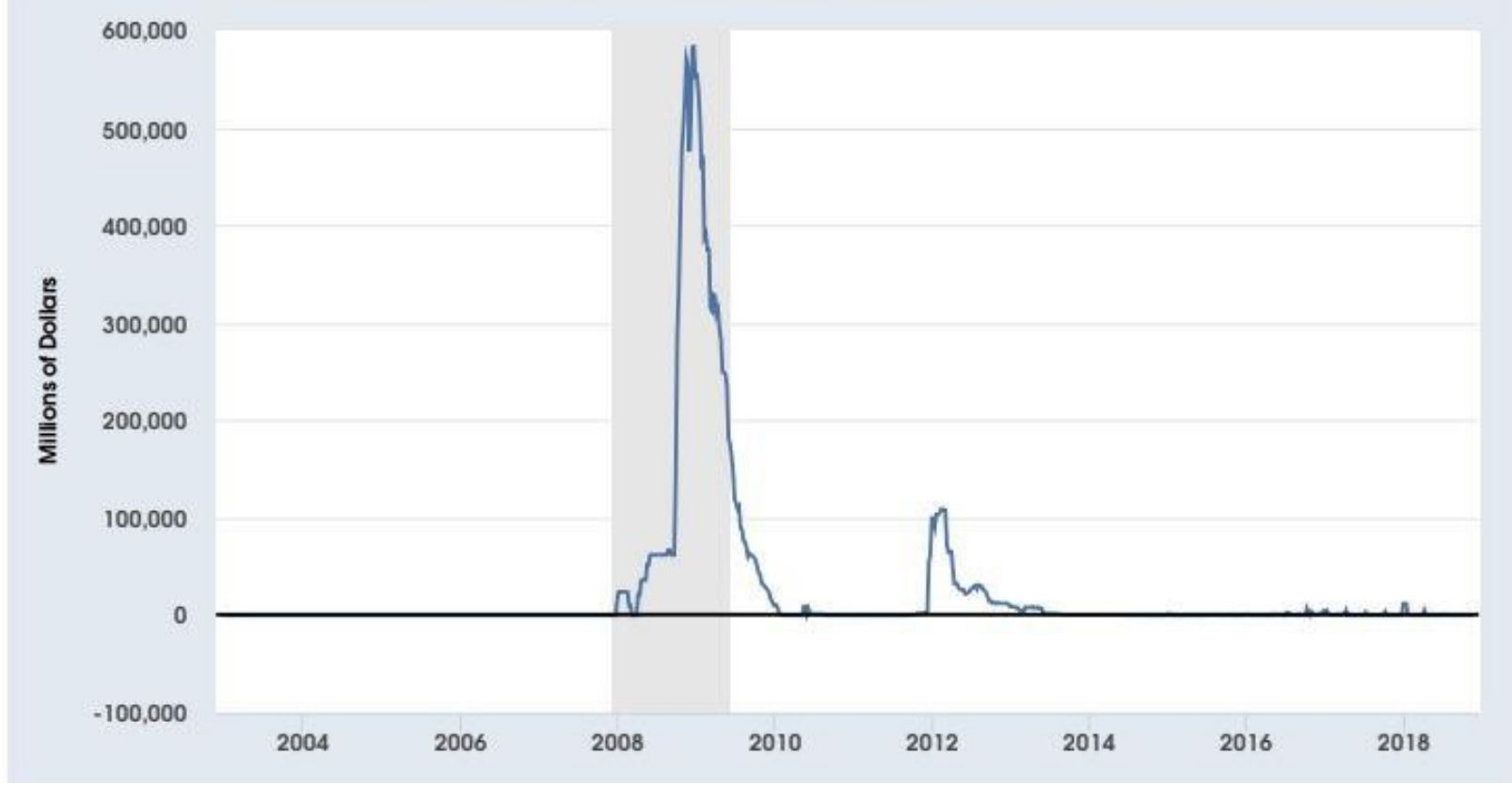

Shaded areas indicate U.S. recessions.

Source: Board of Governors of the Federal Reserve System (US) 
FIGURE 4.11

TERM STRUCTURE OF KAMAKURA ESTIMATES OF CUMULATIVE DEFAULT PROBABILITIES OVER DIFFERENT HORIZONS FOR BANKS PARTICIPATING IN THE FED'S 2016 STRESS TESTS

\begin{tabular}{|c|c|c|c|c|c|c|c|c|c|c|c|c|c|}
\hline Pastito CCE & 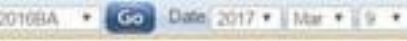 & (1) Model KDP je & - t Term Cinnua & sve? & t) ALL & & - H & $\nabla A L$ & + s & N N & & • & \\
\hline TERM S & RUCTURE & & & & & & & & & Prolle & Tem Stu & & view \\
\hline & & & & & & & & & & & ahation ices & & aload \\
\hline Flecord 1 so 34 & 64 & & & & & & & & & & & & \\
\hline Teker & Compary & Country & Ssp Ratine & $1 \mathrm{Mo}$ & $3 \mathrm{Mo}$ & $6 \mathrm{Mo}$ & $1 Y r$ & $2 \mathrm{Yr}$ & $3 Y_{r} \cdot$ & $4 Y_{r}$ & $5 \mathrm{Yr}$ & $7 \%$ & $10 \mathrm{Yr}$ \\
\hline DeK & DEUTSCHE BANK AG & DEU & B88+ & 0.17 & 0.56 & 108 & 206 & 488 & 6.49 & 8.16 & 1008 & 1737 & 2290 \\
\hline SAN & BANCO SANTANDER SA & ESP & A & 0.04 & 0.15 & 0.37 & 0 os & 292 & 411 & 536 & 705 & 1684 & 2083 \\
\hline BBMA & BBVA & ESP & BEB+ & 006 & 0.20 & 0.45 & 101 & 2.95 & 405 & 522 & 7.20 & 1567 & 1975 \\
\hline 8006 & MUT SUBSEA UFJ FINANCIAL GPP & SPN & A & 0.02 & 0.06 & 0.17 & e.49 & 2.30 & 343 & 472 & 706 & 15.45 & 1979 \\
\hline ALLY & ALLY FINANCINL INC & USA & BB. & 004 & 0.13 & 0.20 & 063 & 2.10 & 3,17 & 4.46 & 6.51 & 1483 & 1935 \\
\hline 601988 & BANK OF CHINA LTD & $\mathrm{CHN}$ & A & 0.07 & 0.23 & 0.43 & 0.82 & 203 & 283 & 385 & 5,16 & 10.22 & 1528 \\
\hline resah & HSEC HDCS PLC & GBR & A & 0.01 & 0.05 & 0.10 & 022 & 1.27 & 2.34 & 391 & 6.07 & 1350 & 1760 \\
\hline PF & PEGIONS FINANCLAL COPP & USA & 688 & 0.01 & 0.03 & 006 & 0.14 & 0.97 & 171 & 276 & 4.51 & 1081 & 1461 \\
\hline IEAN & HUNTINGTON BANCSHARES & USA & see & 0.01 & 0.03 & 000 & D.14 & 0,94 & 1.63 & 264 & 4.36 & 1059 & 1413 \\
\hline TPG & BNP PAPIEAS & FRA & A & 0.01 & 0.03 & 0.05 & 0.11 & 0.76 & 157 & 288 & 4.82 & 1082 & 1527 \\
\hline KEY & KEYCOPP & USA & 6อ8* & $0.0 t$ & 0.03 & 006 & 0.12 & 0.78 & 1.43 & 241 & 4.06 & 9.88 & 13.55 \\
\hline CFO & CITIZENS FINANCLAL GROUP INC & USA & $888+$ & 0.01 & 003 & 006 & 0.11 & 000 & 1.42 & 2.57 & 4.29 & 993 & 1352 \\
\hline คтв & FIFTH THIRD EANICORP & USA & $\mathrm{B8B+}$ & 0.01 & 0.03 & 0.00 & 0.12 & 0.69 & 1.39 & 237 & 390 & 956 & 1305 \\
\hline DON & ZONS BANCCORPOPATION & USA & Bes- & 0,00 & 002 & 003 & 007 & 0.57 & 1.32 & 250 & 437 & 10.44 & 1428 \\
\hline FAC: & BANK OF AGEPACA CORP & USA & $688+$ & 001 & 003 & 0.06 & 0.10 & 060 & 1.21 & 222 & 384 & 9.22 & 1329 \\
\hline MS & MORGNN STANLEY & USA & вев. & 0.01 & 0.02 & 004 & 0.07 & 0.46 & 1.07 & 200 & 300 & $8 n$ & 12.54 \\
\hline sn & SUNTRUST BANKS INC & USA & $\mathrm{BB8}+$ & 000 & 001 & 0.03 & 0.06 & 048 & 1.06 & 196 & 343 & 837 & $11: 32$ \\
\hline cof & CAPITAL ONE FINANCINL COFP & USA & В8อ & 0.00 & 0.01 & 0.02 & 0.06 & 0.40 & 1.03 & 1.79 & 316 & 8.11 & 1070 \\
\hline Bet & BBST CORP & USA & A. & 001 & 0.2 & 003 & 007 & 046 & 096 & 170 & 315 & 781 & 10.44 \\
\hline cina & COMERICA INC & USA & 888. & 0.00 & 0.01 & 002 & 006 & 0.41 & 0.06 & 176 & 313 & 774 & 1050 \\
\hline c & CIIIGROUP INC & USA & ве8+ & 000 & 0.01 & 003 & 0.06 & 0.39 & 0.93 & 181 & 330 & 8.17 & 11.53 \\
\hline WFC: & WEULS FARGO $\&$ CO & USA & A & 000 & 0.01 & 003 & 006 & 0.43 & 0.93 & 174 & 3,12 & 778 & 1038 \\
\hline $\mathrm{sT}$ & STATE STREET COFP & USA & A & 0.00 & 0.01 & 0.02 & 0.06 & 0.40 & 089 & 182 & 291 & 748 & 10.21 \\
\hline 70 & TORONTO DCAINION BNAK & CNN & AA & 0.00 & 000 & 001 & 000 & 0.37 & 0.87 & 152 & 2.82 & 763 & 1022 \\
\hline use & US BANCORP & USA & A* & 0.00 & 0.01 & 003 & 0.06 & 0.39 & 0.83 & 156 & 280 & 711 & 9.43 \\
\hline EK & BANK OF NEW YORK MELLON CORP & USA & A & 001 & 0.02 & 000 & 006 & 0.39 & 0.83 & 161 & 291 & 729 & 10.02 \\
\hline Bato & BANK OF MONTREAL. & CAN & A* & 000 & 0.00 & 001 & 000 & 0.34 & 080 & 140 & 2.65 & 731 & 999 \\
\hline JPM & JPMORGAN CHUSE \& CO & USA & A. & 000 & 0.01 & 0.01 & 0.00 & 0.33 & 0.79 & 1.45 & 270 & 700 & 973 \\
\hline PNC & PNC FINAWCIAL SVCS GROUP INC & USA & A. & 0.00 & 0.00 & 001 & 003 & 0.33. & 078 & 136 & 251 & 678 & 901 \\
\hline Gs & GOLOANN SACHS GROUP INC & USA & Beat & 0.00 & 0.00 & 001 & 002 & 0.29 & 0.72 & 127 & 2.42 & $6 e \theta$ & 930 \\
\hline MTrB & MS T BANK CORP & USA & A. & 000 & 000 & 001 & 002 & 020 & 068 & 1.16 & 2.15 & $60 \%$ & 756 \\
\hline
\end{tabular}


FIGURE 4.12

CUMULATIVE CHANGE IN THE PERCENTILE DISTRIBUTION OF HOUSEHOLD WEALTH OVER THE ROUGHLY TEN YEARS SINCE THE GFC BEGAN (MEASURED IN \$ TRILLION)

\begin{tabular}{|l|c|c|c|c|}
\cline { 2 - 5 } & Top 1\% & $\mathbf{9 0 - 9 9 \%}$ & $\mathbf{5 0 - 9 0 \%}$ & Bottom 50\% \\
\hline 2008: Q3 & 16.65 & 22.98 & 17.97 & 0.34 \\
\hline 2018: Q4 & 30.37 & 38.26 & 28.59 & 1.17
\end{tabular}

Source: Distributional Financial Accounts constructed by staff economists at the Federal Reserve Board. http://www.federalreserve.gov/releases/efa/efa-distributionalfinancial-accounts.htm. 
FIGURE 4.13

30-YEAR CHANGE IN PERCENTILE DISTRIBUTIONS OF US HOUSEHOLD WEALTH SHOWN BY FEDERAL RESERVE FLOW OF FUNDS DISTRIBUTIONAL ACCOUNTS

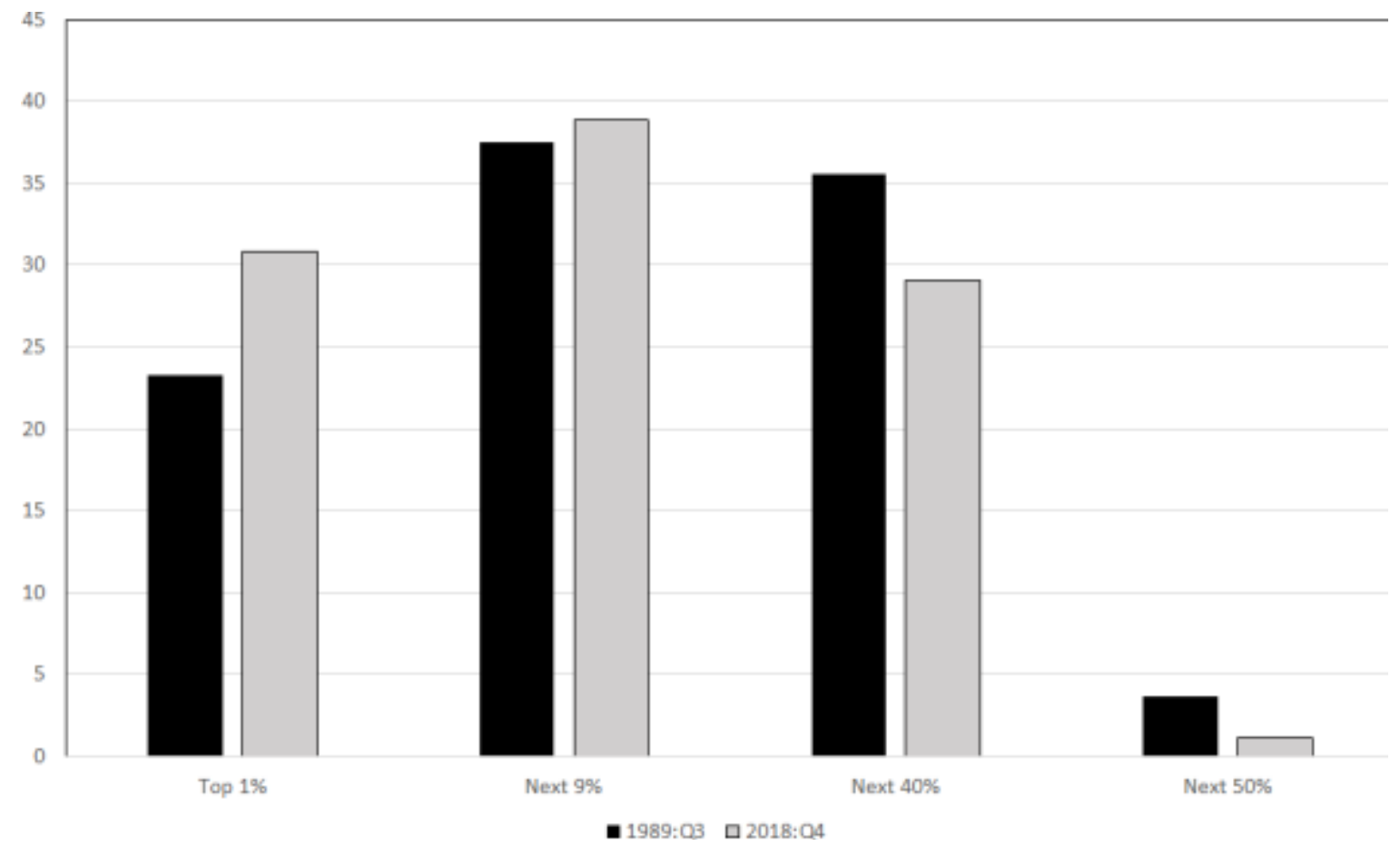

